\title{
Two Possible Wild Hybrids of the White-fronted Goose x Snow Goose
}

by Alex Dzubin

Canadian Wildlife Service, Saskatoon

Natural hybrids between species of reese are not common, although numbers are reported in penned collections. Two possible wild hybrids of a cross between the White-fronted Goose (Anser albifrons) and the Snow Goose (Chen hyperborea) are described from the KindersleyKerrobert districts of Saskatchewan.* On October 5, 1962, I observed two aberran't-appearing geese on Buffalo Colulee Lake $\left(51^{\circ} 46^{\prime} \mathrm{N} ; 109^{\circ} 18^{\prime} \mathrm{W}\right)$, four miles north and four miles west of Coleville. They were examined for an hour, from a vehicle, with a $40-$ power scope from the distance of 175200 yards. Visibility was excellent under a clear sky. No attempt was made to collect the hybrids as they were in a game preserve. The lake was also being utilized as a banding site for White-fronted Geese. The presence of both Snow Geese and White-fronted Geese within 100 yards of the suspected hybrids made direct comparisons possible. In this paper the possible hybrids are designated as " $A$ " and " $B$ ".

It is a pleasure to acknowledge the comments and help given by Don Flook and Jim Bendell.

\section{Description}

In both birds the head color was a mottled dark grey. Bird A had a whitish-grey patch behind the bill which resembled the white forehead of an adult white-front. Bird B had a grey forehead but a lighter grey patch existed on both cheeks, one to one and one-half inches in diameter. The patch was smaller than one which might be found on a Canada Goose and was located closer to the mandibles. As far as could be determined the color about the eye was dark. The bill on bird A was orangepink in color, not unlike that of a few nearby White-fronts, but certainly

\footnotetext{
* Correspondence between Frank H. Brazier, myself, and Mr. Edgar Sibbald of Conquest, Saskatchewan suggests that the latter may have shot a similar hybrid near Kerrobert during the latter part of October, 1963. Unfortunately, the specimen was not saved and few details are available.
}

brighter. Most western Saskatchewan White-fronts have light pink or pink mandibles. Areas of apparent wear, i.e. top and lateral edges of the mandibles, junction of feathers and horny mandible, and rami of the lower mandible, can become quite orange and yellow-orange. Bird $B$ had a definitely light colored pinkishorange bill. The most striking feature was the dark black grinning patch - similar to those of nearby Snow Geese. Mandibles of both A and $B$ did not seem to be as large or as massive as those of Snow Geese but were larger than those of Whitefronts. The neck on both individuals was dark grey, the same color as the head. On bird A this color encompassed the breast area while in $B$ the grey fused into a white breast near the junction of neck and body.

On both birds the belly was pure white with white feathers extending into the under-tail coverts. The tail appeared dark grey in both geese with no apparent whiteness on the rectrices. I was not able to observe the color of the upper tail as it was covered with the folded primaries. Leg color in both A and B was light orange, lighter than in surrounding White-fronts but with an indication of some pink. In both birds the back was dark grey-brown and appeared lightly streaked. The wing coverts were of the same grey-brown color. In general, the color of the upper wing and back was more similar to Whitefront coloring but greyer. However, the tertials were long, white-edged and reminded me of tertials of the Blue Goose (Chen caerulescens). In all, the wings were darker than those of the nearby White-fronts and did not show the blue hue. The overall size of the two birds appeared about one-quarter larger than adult Whitefronts.

\section{Behaviour}

The apparent hybrids were more aggressive than the White-fronts with which they associated. They regularly pecked at nearby geese, 
which tended to avoid the hybrids when they walked through the flock. Their feeding behaviour consisted of seeking tubers and roots in the soft mud, behaviour reminiscent of feeding patterns of Snow Geese. Their general stance, especially when alert and walking, resembled Snow Geese, yet they invariably mixed with White-fronts, even though flocks of Snow Geese were nearby. On October 6 and 11, they were still associated as a couple. On October 6 they returned from a feeding flight with a flock of 35 White-fronts, and on October 11 they were found resting on a mud flat near several hundred Whitefronts. The continued association of the two birds suggests that they may have come from the same brood.

\section{Discussion}

On the basis of the duality of body characters of the two birds and a comparison of my descriptions with published observations of hybrids I submit these sightings as valid hybrid records of a White-front $x$ Snow Goose cross. Salomonsen (1946) describes several hybrids resulting from a mating between a Greenland Whitefronted Goose (A. a. flavirostris) and a lesser Snow Goose from an estate in Denmark. The colors of those hybrids were quite similar to the ones seen at Buffalo Coulee. The legs and feet of one bird were pale orange with webs paler and yellowish pink. The legs on two others were reddish with webs again yellowish pink. In the Saskatchewan birds, both foot and bill colors were nearer Whitefront than Snow Goose. The black gape was typically Snow Goose while the belly was completely white. Salomonsen (1946) took particular note of the grey neck in his specimens and indicated that it resembled the blue phase of the Snow Goose. His specimens also showed a brighter white forehead and cheek spots than the Saskatchewan birds. However, the Danish birds were adults, whereas the Saskatchewan birds may have been immatures. The white foreheads of the latter were ncit as developed as the specimens from Denmark. Lonnberg (1941) had previously described a White-front $x$ Snow hybrid that showed white margins on the tertials - similar to the Saskatchewan birds and certainly a Blue Goose character. Delacour (1954) and Co.och and
Beardmore (1959) have already discussed the Blue-Snow Goose color complex.

Of the five hybrids described by Salomonsen, some show intermediate characters between both parents, and some show definite Blue Goose characteristics. Most body parts and colors were predominantly Snow Goose type. He discusses plumage color differences between male and female hybrids and claims a possible color linkage on the sex chromoscme. Three males had grey-black rumps and heads, while the two females had white backs and rumps. The heads of the females were particularly white. On this basis, the two Saskatchewan birds may have been males.

It is difficult to assign the parents of the hybrids observed in this case to either a light blue-phase-Snow or Snow Goose, since no specimen is available and the hybrids show characters from the two color phases. Hybrids of both Snow Goose and Blue Goose $x$ White-front have been reported numerous times in penned birds (Gray, 1958). The Saskatchewan birds were apparently wild and therefore originated through a natural cross. One can only speculate as to their area of origin. Snow Geese and White-fronts breed in close proximity to each other at Anderson River, N.W.T., while both Snow Geese and a few Blue Geese breed within several miles of the White-front in the Perry River and Thelon River areas, N.W.T. (Barry, p.ers. comm.).

Hybrid matings between Anser $\mathrm{x}$ Chen, Anser x Branta, Anser x Cygnus and Anser sp. x Anser sp. have been reported and documented in great detail by Sibley (1938) and especially Gray (1958). Yearly reports of such hybrids are made by the Wildfowl Trust (Anonymous, 1952). Most of the hybrids have resulted from birds kept together in waterfowl collections. At one time or another White-fronts have apparently crossed with most species of grey, black and white geese. Crosses between White-fronted Geese of the European and Greenland forms with various Snow Goose types (lesser, greater and blue phase) are quite common, although natural hybrids are rare. Wild hybrids, other than those reported by Gray (1958) from White-front $x$ Canada Goose (B. c. 
hutchinsi), have been reported from Sarqaq, on the Nugssauq Peninsula of Greenland, by Salcmonsen (1950). Alpheraky (1905) mentions a young female hybrid resulting from a cross between a White-front and Bean Goose (Anser fabalis). Another White-front $\mathrm{x}$ Snow Goose is apparently described in an early paper by Schenk (1925-26) but I was not able to examine this record. Taverner (1940) mentions that a hybrid specimen of Blue Goose $x$ White-front, taken at Fort Chipewyan, N.W.T., in 1913 , is located in the National Museum of Canada.

\section{LITERATURE CITED}

Alpheraky, Sergius. 1905. The geese of Europe and Asia. London. Rowland Ward Ltd., London.

Anonymous. 1952. Hybrids. Severn Wildfowl Trust Ann. Rept., 5:53 (see also 1950 Rept. 3:38; 1951 Rept. 4:36; 1953 Rept. 6:9; 1954 Rept. 7:53; 1957 Rept. 9:19-20).
Cooch, F. G., and J. A. Beardmore. 1959. Assortive mating and reciprocal differences in the blue-snow goose complex. Nature, 183:1833-34.

Delacour, Jean. 1954. The Waterfowl of the World. Vol. I. London, Country Life Ltd. $284 \mathrm{pp}$.

Gray, Annie P. 1958. Bird hybrids. A check-list with bibliography. Commonwealth Agricultural Bureau. Tech. Comm. No. 13. Farnham Royal.

Lonnberg, E. 1941. Further notes on some interesting goose hybrids. Arkiv for Zoologi. Vol. 33 B No. 13. (Not seen; in Salomonsen 1946.)

Salomonsen, Finn. 1946. Notes on some goose hybrids. Goteborgs Kungl Vetenskaps och Vitterhets - Samhalles Handlingar. Ser. B Band 3, No. 10: 1-14.

Salomonsen, Finn. 1950. The Birds of Greenland. Copenhagen. Ejnar Munksgaard. 608 pp.

Schenk, Jakeb. 1925-26. Feher vadludak magvarorszager on - Weisse wildganse in Ungarn. Aquila, 32-33: 139-146.

Sibley, C. L. 1938. Hybrids of and with North American Anatidae. Proc. Intern. Ornith. Congr. 9: 327-335. Rouen.

Taverner, P. A. 1940. The nesting of Ross's Goose Chen rossi. The Canad. Field-Nat., 54 (9): $127-130$.

\section{Fourth Annual May Day Bird Count}

\section{Regina Natural History Society, May 16, 1964}

The Regina May bird census on May 16, 1964, recorded 141 species of birds in an area approximating the circle of 15-mile radius described for the Birds of Regino (1961). Vic Wilshire was in charge of organizing the parties in the six zones. Of special interest was the observation for the first time in the Regina area, of a Brewer's Sparrow (see article by R. W. Nero, P. 99).

SPECIES LIST: Red-necked Grebe 4; Horned Grebe, 39; Eared Grebe, 117; Western Grebe, 19; Pied-billed Grebe, 10; Double-crested Cormorant, 3; Great Blue Heron, 2; Blackcrowned Night Heron, 18; Mute Swan, 5; Whistling Swan, 5; Trumpeter Swan, 1; Canada Goose, 245 (including 90 young); Mallard, 314; Gadwall, 77; Pintail, 79; Green-winged Teal, 18; Blue-winged Teal, 320; American Widgeon, 182; Shoveler, 94; Redhead, 40; Ring-necked Duck, 1; Canvasback, 83; Lesser Scaup, 100; Common Goldeneye, 1; Bufflehead, 1; Ruddy Duck, 79; Red-tailed Hawk, 3; Swainson's Hawk, 5; Marsh Hawk, 4; Sharptailed Grouse, 13; Ring-necked Pheasant, 4; Gray Partridge, 42; Sora, 16; American Coot, 189; Semipalmated Plover, 1; Killdeer, 89: American Golden Plover, 474; Black-bellied Plover, 9; Ruddy Turnstone, 1; Common Snipe, 2; Upland Plover, 8; Spotted Sandpiper, 14; Solitary Sandpiper 6; Willet, 48; Lesser Yellowlegs, 17; Pectoral Sandpiper, 274; Whiterumped Sandpiper, 4; Baird's Sandpiper, 11; Least Sandpiper, 73; Long-billed Dowitcher, 32; Stilt Sandpiper, 11; Semipalmated Sandpiper, 36; Marbled Godwit, 36; Sanderling, 21 ; Ámerican Avocet, 15; Wilson's Phalarope, 170; Northern Phalarope, 35; Ring-billed Gull' 47; Franklin's Gull, 155; Common Tern, $40+$; Black Tern, 292; Rock Dove, 54; Mourning Dove, 60; Great Horned Owl, 3; Burrowing
Owl, 7: Short-eared Owl, 1: Common Nighthawk, 3; Belted Kingfisher, 1; Yellow-shatted Flicker, 9 (plus 3 hybrids); Ked-shatted Flicker, 1; Downy Woodpecker 1; Eastern Kingbird, 37; Western Kingbird, 73; Eastern Phoebe, 1: Say's Phoebe, 3; Traill's Flycatcher, 11; Least Flycatcher, 47 (with 24 Empidonax not identified): Western Wood Pewee, 3; Olivesided Flycatcher, 1; Horned Lark, $425 \pm$; Tree Swallow, 51 $\$$; 'Bank Swallow, 24; Barn' Swallow, 86; Cliff' Swallow, 1; Purple Martin, 26; Black-billed Magpie 61; Common Crow, 126; Red-breasted Nuthatch, 1; House. Wren, 8; Brown Thrasher, 34; Robin, 81; Swainson's Thrush, 56; Grey-cheeked Thrush, 13; Veery, 1; Ruby-crowned Kinglet, 3; Water Pipit, 1; Cedar Waxwing, 1; Loggerhead Shrike, 20; Starling, 18; Solitary Vireo, 1; Philadelphia Vireo 1; Warbling Vireo, 2; Tennessee Warbler, 10; Orange-crowned Warbler, 23; Yellow Warbler, 112; Magnolia Warbler, 1; Myrtle Warbler, 53; Blackpoll Warbler, 6; Palm Warbler, 2; Northern Waterthrush, 5; Mourning Wárbler, 1; Yellowthroat, 8; American Redstart, 9; House Sparrow 395t; Western Meadowlark, 192; Yellow-headed Blackbird 220; Red-winged Blackbird, 971; Baltimore Oriole, 50; Brewer's Blackbird, 172; Common Grackle, 92 + ; Brown-headed Cowbird, 193; Rose-breasted Grosbeak, 4; American Goldfinch, 2; Rufous-sided Towhee, 14; Lark Bunting, 41: Savannah Sparrow, 73; Baird's Sparrow, 3; Vesper Sparrow, 69; Lark Sparrow 1; Chipping Sparrow, 646; Clay-colored Sparrow, 837; Brewer's Sparrow, 1; Harris' Sparrow, 41; White-crowned Sparrow, 61; White-throated Sparrow, 18; Lincoln's Sparrow, 14; Swamp Sparrow, 3; Song Sparrow, 29; McCown's Longspur, 69; Lapland Longspur, 3246; Chestnut-collared Longspur, 77. - Dorothy Wode, compiler. 